\section{New Trends and Issues Proceedings on Humanities and Social Sciences}

Issue 1 (2017) 519-524
ISSN 2421-8030

www.prosoc.eu

Selected paper of 8th World Conference on Educational Sciences (WCES-2016), 4-8, February 2016, University of Alcala, Madrid, Spain

\title{
Sociocultural and academic adaptation of international students in a higher education institution
}

Konyukhova Tatiana V. ${ }^{*}$, Tomsk Polytechnic University, 30, Lenin Ave., Tomsk, 634050, Russia.

Konyukhova Ekaterina T. , Kemerovo State University in Novokyznetsk. Tsiolkovskogo St. 23, Novokuznetsk, 654041, Russia.

Zavyalova Zinaida S.c , Tomsk Polytechnic University, 30, Lenin Ave., Tomsk, 634050, Russia.

Lokotosh Yana V. ${ }^{\text { }}$, Tomsk Polytechnic University, 30, Lenin Ave., Tomsk, 634050, Russia.

Kashpur Valeria V. ${ }^{\text {e }}$, Tomsk State University, 30, Lenin Ave., Tomsk, 634050, Russia.

\section{Suggested Citation:}

Konyukhova, T. V., Konyukhova, E. T. Zavyalova, Z., Lokotosh, Y. \& Kashpur, V. (2017). Sociocultural and academic adaptation of international students in a higher education institution. New Trends and Issues Proceedings on Humanities and Social Sciences. [Online]. 01, pp 519-524. Available from: www.prosoc.eu

Selection and peer review under responsibility of Jesus Garcia Laborda, University of Alcala, Spain

${ }^{\circ} 2017$ SciencePark Research, Organization \& Counseling. All rights reserved.

\begin{abstract}
This paper considers the issues of sociocultural and academic adaptation of international students at Tomsk Polytechnic University (Russia). The experiment lasted in March 2015. A study based on the techniques of K. Rogers, R. Diamond, J. Phinney, D. Katz and K. Braly, has showed that ethnic identity is fully recognized by $31 \%$ of students. Chinese students have a strong sense of belonging to their ethnic group, while students from Germany show less ethnic identification. Students from Mongolia show the lowest level of social adaptation. The authors have identified factors influencing adaptation of international students and recommended to train supervisors, who have multicultural competences, develop university adaptation programs and complexes of educational and methodical support, etc.
\end{abstract}

Keywords: Adaptation, education, ethnic identity, international students, motivational readiness.

* AdDRESS fOR CORRESPONDENCE: Konyukhova Tatiana V., Tomsk Polytechnic University, 30, Lenin Ave., Tomsk, 634050, Russia.

E-mail address: konykhova@tpu.ru / Tel.: +7-913-880-4400 
Konyukhova, T. V., Konyukhova, E. T. Zavyalova, Z., Lokotosh, Y. \& Kashpur, V. (2017). Sociocultural and academic adaptation of international students in a higher education institution. New Trends and Issues Proceedings on Humanities and Social Sciences. [Online]. 01, pp 519-524. Available from: www.prosoc.eu

\section{Introduction}

The relevance of the study is determined by the rapid expansion of international academic contacts of Russian universities in recent times. Tomsk Polytechnic, as one of the leading universities in Russia, has a policy aimed at establishing effective academic collaboration with international educational institutions that would give a university a stable increase in ranking to move into the top 100 (2012). The issue of academic cooperation is considered in the "Concept of the State Migration Policy of the Russian Federation until 2025" (2012), and it is expected that the number of students from abroad will continue to grow in the next decade. Therefore, Tomsk Polytechnic University (hereinafter TPU) is focused on creating new social and pedagogical technologies, based on a strategy of reviewing the indicators of training quality and improving sociocultural and academic adaptation of international students.

The term adaptation means the integrated, multi-faceted phenomenon, which is referred to as both a process and a state of adaptation, and considered in various fields of science. Researchers distinguish different types of adaptation (Ivanova \& Titkova, 1993; Krivcova, 2011; Merton, 1949; Parsons, 1968; Vitkovskaja \& Trocuk, 2011), which generally characterize a single process involving multiple factors, but it has been overlooked that a learning mindset is not a growth one, since some students have not developed motivational readiness to overcome the difficulties they my face in new sociocultural and academic conditions including a language barrier.

The disposition of international students that is their willingness to get adapted in the new environment provides an implementation of adaptive abilities correlated with the goals of an individual (Uznadze, 1961). A stable type of disposition is one based on a national character. Conservative and clear, it is passed down from generation to generation and mediates the actions and behavior of a particular ethnic community. It is an indicator of mental setting of a student, and, therefore, must be considered in higher education.

Based on the theory of D.N. Uznadze (1961) and V.A. Yadova (1975), we believe, that the disposition becomes a motivational factor for the successful adaptation of the student in a new academic environment. It influences the way of learning, the level of involvement in educational and social activities, and the degree of motivation for mastering the profession. Therefore, the goal of this study is to explore the willingness of international students (The case of Tomsk Polytechnic international students) to adapt to a new sociocultural and academic environment.

\section{Methods}

We conducted an experiment to study how international students get adapted in the sociocultural and academic environment of TPU. The object of the study was participants of the TPU Student Academic Exchange Program: international students on exchange and studying full-time. We used a quota sample that considered the nationality and citizenship of the respondents (Germany, China, Mongolia, Vietnam), and age (18-25 years). Sample size was 43 people. The experiment lasted for one month in March 2015. Processing of the results was carried out from 04.04.2015 to 05. 10.2015.

Firstly, we introduced to the students the social and psychological portrait of a certain ethnic group, and then using the method of observation, we revealed if a person had some of these characteristics or not. The willingness of a student to be included into a new social and academic environment, to study hard, and overcome a language barrier was revealed using a specially developed questionnaire with closed and semi-closed questions. As a diagnostic tool, we used the methodology of K. Rogers and R. Diamond (1954). Ethnic identity was explored with the method of J. Phinney (2007), and the method of "assigning characteristics" (1933). Empirical data were processed using Statistical Package for the Social Sciences SPSS 22.0. 
Konyukhova, T. V., Konyukhova, E. T. Zavyalova, Z., Lokotosh, Y. \& Kashpur, V. (2017). Sociocultural and academic adaptation of international students in a higher education institution. New Trends and Issues Proceedings on Humanities and Social Sciences. [Online]. 01, pp 519-524. Available from: www.prosoc.eu

\section{Results and discussion}

In direct contact with the students, we have noticed that not all students (18\%) have a desire to learn or improve their knowledge of Russian, as evidenced by the following statements: " do not want to learn the language," "answer when asked, generally, I try to be silent "," was not going to come to Russia, parents made me"," will not come to Russia again", "Russian is hard to speak ","sometimes I use cribs"," learning the language is not necessary, "on return I will use either the mother tongue or English, " important to get a diploma only"," the degree is important for a career in the Motherland". $15 \%$ of the students are not willing to adapt to the linguistic and social environment, but almost all male students use obscene Russian words in casual conversation.

Our study has shown that international students build their learning strategy in different ways. The Chinese students are more passive, and prefer to be paid more attention, even to the detriment of the others. In the process of adaptation, they use certain features inherent in the national character such as patience, the ability to endure the difficulties, proactiveness, and the ability to pursue the goals. But the "us" and "them" division and the value hierarchy of national pride and superiority make it difficult for the Chinese students to enter the new sociocultural environment, and they tend rather to accommodate then get adapted. We would call it pseudo-adaptation. By contrast, students from Vietnam are more independent; their motivational and national features include working efficiency, diligence and perseverance. Germans showed themselves pragmatic, introversive, conscientious, punctual, accurate, diligent and with a technical mind-set.

The adaptation of international students to the new socio-emotional conditions depends on the attitude of the host country, mutual sympathy, antipathy, stereotypes, attitudes (Kamara Ishaka, 2012), sociocultural and psychological characteristics of different ethnic groups. All these factors can help us to understand and explain the readiness of international students to adapt to the different sociocultural and academic environment. A negative impact on the process of adaptation of international students is made by Russian students' cheating in class, missing lessons, and demonstrating disrespect for the professor. This behavior complicates the adaptation process, but, as shown by our study, $21 \%$ of international students tend to copy these behavioral models by the end of training period.

The difficulties of adaptation in a higher educational institution that are students have been going through go through are similar to those identified in the studies of other authors. Students from China experience difficulties in the field of study (Vitkovskaja \& Trocuk, 2011). About $80 \%$ of students have a cultural and language barrier (Dement'eva, 2008; Droggina, 2013). During the first years of study the greater part of problems seem to be solved, but there are still a growing number of senior undergraduate students who begin to have serious learning difficulties. Our study has shown that the common positive factor of adaptation for the majority of international students $(71 \%)$ is the value of education, which highly motivates the students' behavior and contributes to their involvement in educational and social activities.

Therefore, the adaptation of international students in a new country is related to the psychophysiological, educational and cognitive difficulties such lack of language skills, differences in education systems, new requirements and knowledge control, social and cultural challenges of the new academic environment, moral and practical standards of behavior and socialization.

The results of our study have showed that the factors of life and learning satisfaction, similar to the existing research results in the literature (Krivcova, 2011; Londadgim, 2012, etc.) are good relationships with others; the desire of teachers to transmit knowledge and professional skills, the use of information technology; safety of the city life, education as an opportunity to be culturally and professionally mobile.

$31 \%$ of the students fully identify themselves with their ethnic group, $49 \%$ - in part, $20 \%$ - do not identify (Figure 1). German students are inclined to have the weakest identification of all. It's probably explained by a stronger integration of the European nations. Chinese students have shown the strongest ethnic identification. 
Konyukhova, T. V., Konyukhova, E. T. Zavyalova, Z., Lokotosh, Y. \& Kashpur, V. (2017). Sociocultural and academic adaptation of international students in a higher education institution. New Trends and Issues Proceedings on Humanities and Social Sciences. [Online]. 01, pp 519-524. Available from: www.prosoc.eu

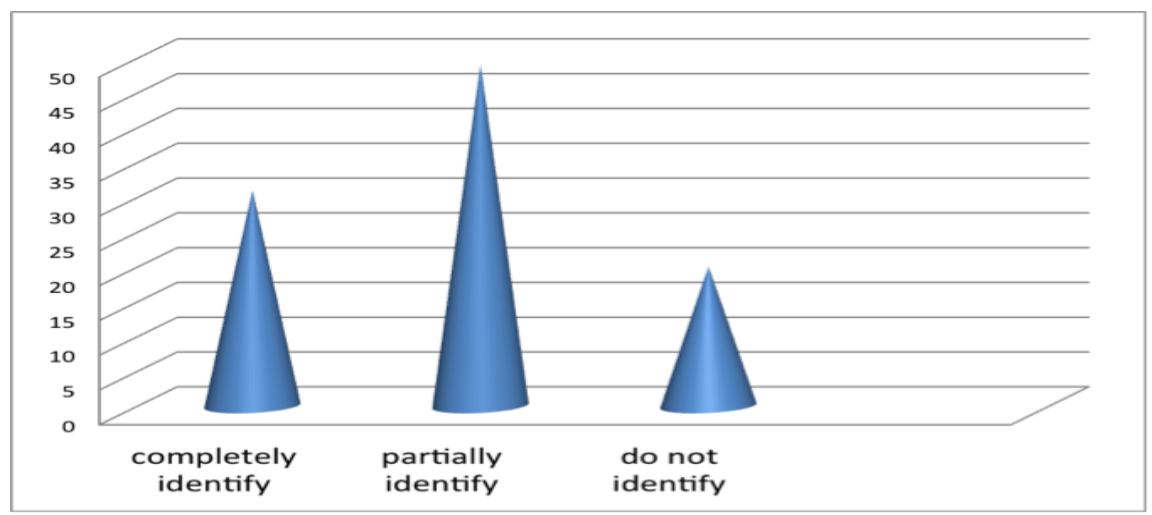

Figure 1. Ethnic origin of international students (\%)

Percent of the students who agree with ethno-psychological characteristics of their nation is: Germans - 41\%, Chinese - 57\%, Vietnamese - 54\% Mongolians - 52\% (Figure 2). We considered these results when creating a program of adaptation for international students at TPU.

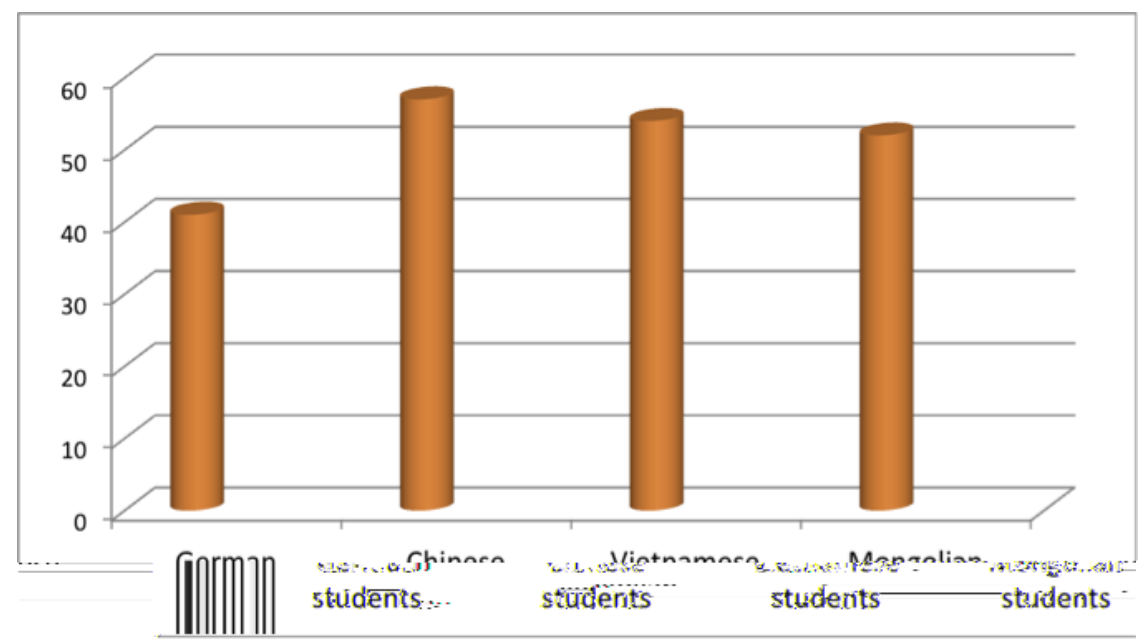

Figure 2. Acceptance of ethno psychological characteristics by international students (\%)

A comparative analysis of the parameters of social and psychological adaptation of the students under study has shown that the indicators of adaptation such as self-acceptance, emotional comfort, internal control and loyal attitude to others are significantly higher in the sample of the highly adapted than in sample of low-adapted students. Students with a low level of adaptation are less emotionally stable; they tend to hyperbolize the role of external circumstances, and are less active in solving their problems.

The analysis of the results has shown (Figure 3) that the students from Germany have the highest level of adaptation (52.4\%); they are focused on self-acceptance, loyal to others, emotionally stable, internal and comfortable in the new environment, but showing no dominance. The Chinese students' adaptation level is $51.2 \%$; they are focused on themselves, experience emotional comfort, less loyal others, internal and dominant. The Vietnamese' adaptation level is $49.7 \%$; they are focused on the acceptance of others, internal, passive, often experience emotional discomfort, disposed to excessive self-criticism. The lowest level of adaptation (46.8\%) was shown by the Mongolian students; they are internal, passive, emotionally comfortable, show a low level of self-acceptance and try to avoid problems. The Chinese students have shown the lowest level of acceptance of others (35.8\%), while the Mongolians have shown the highest. The Chinese feel the most emotionally comfortable (57.3\%), 
Konyukhova, T. V., Konyukhova, E. T. Zavyalova, Z., Lokotosh, Y. \& Kashpur, V. (2017). Sociocultural and academic adaptation of international students in a higher education institution. New Trends and Issues Proceedings on Humanities and Social Sciences. [Online]. 01, pp 519-524. Available from: www.prosoc.eu

while the Vietnamese are the most emotionally distressed (66.6\%). The Chinese also have the highest level of self-acceptance and self-containment (58.8\%), while the students from Germany, Vietnam and Mongolia have shown the similar results (50.1\%). The desire to dominate was shown by $34.2 \%$ of the students from Vietnam, $34.9 \%$ - from China, at 30.9\% - from Mongolia and Germany.

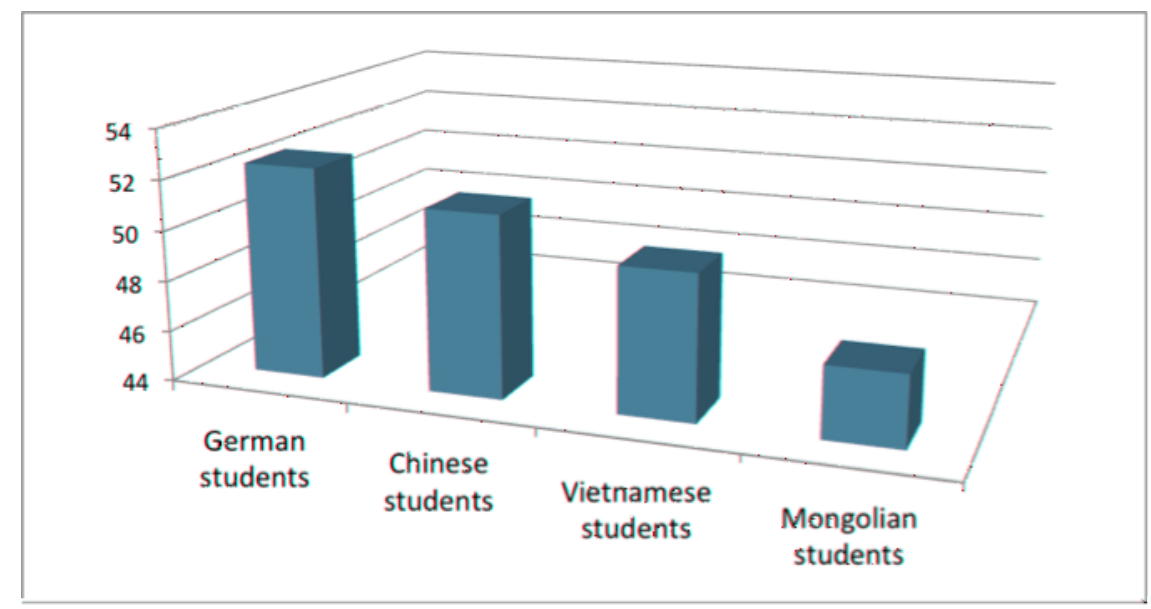

Figure 3. Level of adaptation of international students (\%)

Among the major reasons for failure in overcoming a language barrier, there were the following mentioned: "difficult to read books in Russian", "difficult to organize my life to prepare for classes", "noisy dorm", "do not like to go to the library", "doubt if I speak correctly", "sometimes the teacher is not supportive". Our conversation with the teachers has revealed that the Chinese students do not try to take the initiative in finding more information, while the Vietnamese and Mongolians are the most hard-working, diligent, and responsible in class.

\section{Conclusion}

Meeting the challenges of creating optimal conditions for the successful adaptation of international students almost entirely is a mission of the university. An effective tool for managing sociocultural and academic adaptation is the coherent cooperation of all the university departments.

TPU provides the adaptation of international students through training and retraining of professors, curators, and university staff who work with international students. This training includes multicultural competences. Staff is trained to be able to effectively utilize knowledge gained.

TPU Centre for International Education successfully uses proven technologies to facilitate the linguistic adaptation of international students. According to the majority of Russian researchers (Londadgim, 2012; Sjuj Cjun', 2015, etc.), the time allotted for the study of the Russian language before students enter the basic training program is not enough. TPU has been developing the modern educational and methodical support of the academic process such as English and Russian programs and methodical materials for individual courses that would create students' positive motivation and interest in language learning. To study adaptation characteristics Institute of International Education and Language Communication of TPU plans to continue research that would sum up the teaching experience and experimental materials obtained from the studies as the given one.

Another important task is to organize the work of administrative staff, orienting them to master a foreign language and knowledge about the ethno-cultural characteristics of students through special lectures, seminars and training courses.

Our study has shown that the characteristics of international students' adaptation in the new academic environment are determined by a complex of factors and influenced by the degree of willingness of an individual to be included into the new sociocultural space. This degree differs in each 
Konyukhova, T. V., Konyukhova, E. T. Zavyalova, Z., Lokotosh, Y. \& Kashpur, V. (2017). Sociocultural and academic adaptation of international students in a higher education institution. New Trends and Issues Proceedings on Humanities and Social Sciences. [Online]. 01, pp 519-524. Available from: www.prosoc.eu

ethnic group and the differences must be taken into account when developing university adaptation programs for international students. Successful adaptation can help the adequate interaction of international students with the sociocultural and academic environment of the university by influencing their emotional state, personal development, social status, Russian language skills, and understanding of how important their future profession is to society.

\section{References}

Dement'eva, S.V. (2008). Vuzy Rossii kak mehanizm adaptacii migrantov (v kontekste sociologicheskogo i filosofskogo analiza). Izvestija Tomskogo politehnicheskogo universiteta, 3 (313), 158-164.

Droggina, D.S. (2013). Izuchenie adaptacii inostrannyh studentov: diskussija o metodologii. Jempiricheskie issledovanija. Universitas, 1 (3), 33-47.

Ivanova, M.A., Titkova, N.A. (1993). Social'no-psihologicheskaja adaptacija inostrannyh studentov pervogo goda obuchenija $v$ vuze: Metodicheskie rekomendacii prepodavateljam. Saint Peterburg, SPb.: SanktPeterburgskij gos. tehn. un-t.

Jadov, V.A. (1975). O dispozicionnoj reguljacii social'nogo povedenija lichnosti. Metodologicheskie problemy social'noj psihologii. Moscow, M.: Progress. Retrieved from http://ecsocman.hse.ru/text/16953599/.

Kamara, I. (2012) Inostrannye studenty V Rossii: problemy social'noj adaptacii. Teorija i praktika obschestvennogo razvitija, 8, 82-85.

Katz, D. \& Braly, K. W. (1933). Racial stereotypes of one-hundred college students. Journal of Abnormal and Social Psychology, 28, 280-290.

Koncepcija gosudarstvennoj migracionnoj politiki Rossijskoj Federacii na period do 2025 (2012). Retrieved from http://www.fms.gov.ru/upload/iblock/07c/kgmp.pdf.

Krivcova, I.O. (2011). Sociokul'turnaja adaptacija inostrannyh studentov k obrazovatel'noj srede rossijskogo vuza (na primere Voronegskoj gosudarstvennoj medicinskoj akademii im. N.N. Burdenko). Fundamental'nye issledovanija, 8, 284-288.

Londadgim, T. (2012). Sociokul'turnaja adaptacija inostrannyh studentov, obuchajuschihsja $v$ rossijskih vuzah. Retrieved from Russian State Library (http://dlib.rsl.ru/01005512784).

Merton, R. K. (1949). Social theory and social structure. New York, NY: Free Press.

Parsons T. (1968). Knowledge and Society - American Sociology. New York, NY: Basic Books.

Phinney, J. S. \& Ong A.D. (2007). Conceptualization and measurement of ethnic identity: Current status and future directions. Journal of Counseling Psychology, 54, 271-281.

Rogers, C. R. \& Rosalind, F. D. (1954). Psychotherapy and personality change: Coordinated research studies in the client-centered approach. Chicago: University of Chicago Press.

Sjuj Cjun' (2015). Problemy adaptacii inostrannyh studentov v obrazovatel'noj srede // III megdunarodnyj nauchno-obrazovatel'nyj forum chelovek, sem'ja i obschestvo: istorija i perspektivy razvitija. Retrieved from http://socialforum3.kspu.ru/ru/articles/89-problemy-adaptatsii-inostrannykh-studentov-vobrazovatelnoj-srede.

Strategija 2020: Novaja model' rosta - novaja social'naja politika (2012). Retrieved from http://2020strategy.ru/documents/32710234.html.

Uznadze, D.N. (1961). Jeksperimental'nye osnovy psihologii ustanovki. Tbilisi, Izdatel'stvo AN Gruzinskoj SSR.

Vitkovskaja, M.I., \& Trocuk I.V. (2011). Adaptacija inostrannyh studentov k uslovijam gizni i ucheby v Rossii (na primere RUDN). Vestnik Peoples' Friendship University of Russia, 4, 70-74. 